\title{
SMES DEVELOPMENT AND CORRUPTION: CASE OF KAZAKHSTAN
}

\section{Gulimzhan SULEIMENOVA ${ }^{1}$, Aigul SADVOKASSOVA ${ }^{2}$, Botagoz RAKISHEVA ${ }^{3}$, Arman NURMAGANBETOV ${ }^{4}$}

\author{
Academy of Public Administration under the President of Republic of Kazakhstan \\ E-mails: ${ }^{1}$ gk.suleimenova@gmail.com; ${ }^{2}$ Aigul.Sadvokassova@apa.kz; \\ ${ }^{3}$ bota_r@mail.ru; ${ }^{4}$ anurmaganbetov@gmail.com
}

Received 10 October 2017; accepted 14 January 2018

\begin{abstract}
The article presents a study of the corruption perception and the involvement of SMEs in corruption practices. The main goal of the paper is to provide an analysis of corruption perception of the SMEs representatives, its parts and research methodology to provide an adequate picture and analysis of corruption of the Kazakhstan. For obtaining a comparative picture, we interviewed 500 representatives of SMEs and 500 civil servants. We used a mass survey (face-to-face) method.

The results show that the presence of "gap" between perception of corruption and degree of the respondents' involvement in corrupt practices. The respondents believe that corruption is widespread, but they themselves were rarely involved in corrupt practices. The key message is that the SMEs representatives consider this problem to be acute, but they are not ready to talk about their own experience in this regard.
\end{abstract}

Keywords: corruption, institutional environment, Kazakhstan, perception, SMEs, survey.

JEL Classification: L26, O17, O43.

\section{Introduction}

The modern world is experiencing a period of global changes and transformations. The macroeconomic environment in the world is becoming less predictable against a backdrop of increased competition for resources and sphere of influence, intensified migration flows, and the growing number of hotspots of tension (OECD 2017a). These changes have given rise to many problems negatively affecting the development of SMEs. At the same time, corruption remains a significant factor influencing development of SMEs. The multifaceted impact of corruption on SMEs was noted. It manifests itself in the form of administrative barriers to market entry, artificial complication of business activities, additional costs, and declining profitability (e.g. Galli et al. 2017, Suleimenova 2005, e.g. Golovshchinsky et al. 2004).

Kazakhstan, as one of the few Central Asian countries that managed to achieve positive results in political, economic and social spheres, today faces new challenges in the sphere of state policy and administration. The government of Kazakhstan understands that the key "ingredient" for economic growth is a dynamic development of SMEs. The period of economic crisis, which followed the period of high rates of economic growth in the country, requires identification of the reasons for low rates of the SMEs development.

Whereas in many countries of the world SMEs significantly contributes to GDP and employment, the economy of Kazakhstan has not reached the same levels, in spite of the fact that Kazakhstan ranked the 35th position in the World Bank rating "Doing Business 2017", increasing its rating by 16 points compared to "Doing Business 2016". Kazakhstan entered the top 10 countries with a high number of reforms to improve the business climate. The World Bank marks the country as the best reformer for the fourth time in the last 12 years. The country took the third place in regards to the "Protecting Minority Investors" indicator (Doing Business 2017). Systematic work of the Government of the Republic of Kazakhstan promoted improvement of positions in the "Doing Business" rating. Thus, unprecedented measures

Copyright $\odot 2018$ The Authors. Published by VGTU Press.

This is an Open Access article distributed under the terms of the Creative Commons Attribution License (http://creativecommons.org/licenses/by/4.0/), which permits unrestricted use, distribution, and reproduction in any medium, provided the original author and source are credited. 
have been taken to improve the business environment and reduce administrative pressure on business through reforming existing legislation, improving regulatory approval system, simplifying the procedures for business creation and optimization of state means of control and supervision.

At the same time, the World Economic Forum report notes that corruption ranks third among most serious business problems in Kazakhstan (Schwab 2017: 220). The country's rating in Corruption Perceptions Index reported by Transparency International is not entirely satisfactory. Kazakhstan holds the 131-st position among 175 countries (CPI 2016).

In our opinion, the lack of practical experience in developing market-type institutions in the transition period affected the quality of the institutions created. The metarules developed in the previous period did not contribute to the process of "transplanting" institutions and emergence of the working regulations system. New economic conditions continue to be strongly influenced by the previously dominant system. The current situation of the SMEs institutional environment can be characterized as non-optimal. The non-optimal structure of the institutional environment is explained by the fact that it fails to provide the SMEs representative with necessary information on prices that allows him or her to comply with all the rules and pay for the services of the relevant structures. In particular, one part of the rules and the SMEs institutional environment procedures expands the boundaries of their activities, removes barriers to exchange and maximizes the cost of resources allocation, while the other - prevents such optimization, narrows down potentialities of economic agents, determines waste of private and public resources. As a result, the economy is dominated by informal relations allowing performing economic operations, bypassing the norms of "written" law within the framework of informal rules using alternative mechanisms for resolution of distributional conflicts.

This fact makes actual the need to study attitude of the SMEs representatives to corruption, institutional environment that forms the institutional and legal conditions for business activities, designed to promote the fullest implementation of economic potential and increase the SMEs competitiveness in the context of their inclusion in the global economic system. The main goal of the paper is to provide an analysis of corruption perception of the SMEs representatives, its parts and research methodology to provide an adequate picture and analysis of corruption of the Kazakhstan.

\section{Theoretical framework}

SMEs contribute a lot to the socio-economic development of the country under favorable conditions (OECD 2017b, Ayandibu and Houghton 2017, e.g. Virglerová et al. 2016,
Adamoniene and Andriuscenka 2013). Aldrich H.E. and Wiedenmayer G. wrote in this regard that "social and political environment can either stimulate or destroy entrepreneurial initiatives ... Private initiatives can be successful, better "match" its environment and maximize benefits from interactions under favorable conditions" (Aldrich and Wiedenmayer 1993).

Researches have shown that corruption is a deterrent to the development of SMEs (e.g. Mahfuzur et al. 2017, e.g. Ronald et al. 2015). Thus, widespread corruption in a country has a negative impact on economic growth (e.g. Gamberoni et al. 2016, Uruzbaeva 2016). This has a particularly impact on reducing tax revenues, developing "grey" business zones, etc. It should be noted that there are a lot of publications devoted to SMEs and corruption issues. Meanwhile, the conclusions drawn from the research of perceptions of corruption among business representatives based on survey, regression and empirical analyzes differ. For example, the SME Managers survey conducted in 2013 by the Institute for Economic and Enterprise Research found that the higher the degree of corruption, the more negatively SME Managers consider the institutional environment. Firms must pay bribes to obtain economic benefits (IEER 2013). A research of the All-Russian NGO of Small and Medium-sized Businesses, conducted in 2014, revealed that "mainly civil servants are interested in corruption links, and entrepreneurs are forced to "adapt" to the current situation" (OPORA NKO 2014). Thus, according to Xun W., Chandramohan K., Bali A.S., a "vicious cycle of bribery and corruption" is being formed. The vicious circle begins when firms are forced to practice bribery because of the high level of corruption in their operating environment. The increased participation of firms in the practice of bribery further contributes to the perception of high corruption. In turn, this makes the practice of bribery even more uncontrollable (e.g. Xun et al. 2016). Although, Sorin M.S. Krammer argues that bribery plays a positive role in the introduction of innovation. Firms deliberately pay bribes to bypass bureaucratic procedures (Krammer 2016).

The findings of the research by Collins J. D., McMullen J. S., Reutzel C. R are quite interesting. Thus, a survey of Indian entrepreneurs revealed that the firms do not agree that corruption is widespread. At the same time, nonproductive firms believe that there is no justice due to corruption (e.g. Collins et al. 2016).

All the same, the existence of a negative link between competition and corruption is proved. In such a situation, if the country sets a goal to develop the production sector, the main measures should be aimed at preventing corruption between civil servants and businessmen (Emerson 2006). One of the significant factors of the survival of firms is the control of corruption (Shagbazian and Aistov 2017). At the same time, representatives of SMEs believe that strict 
control over the actions of civil servants is the most effective measure to eliminate corruption (Skriba and Urban 2015). It should be noted that international institutions have proposed deregulation as one of the tools to control corruption. Through the regression analysis of the data, M. Fazekas argues that deregulation of the approval documents issuance process helps in reducing the perception of bribery and petty corruption, but the effectiveness of this tool is not high in controlling state favoritism (Fazekas 2017).

Thus, it can be concluded that various studies in general confirm that corruption and bribery impede the development of SMEs. At the same time, SMEs for strategic reasons resort to bribes to overcome administrative and market barriers.

\section{Methodology}

The corruption assessment in the business sector helps to determine the overall level of corruption in the country or sector of its economy and identify the areas in which corruption is highest and should be considered a priority issue. Regular assessment of the level of corruption is an information source of data on the factors that generate corruption in its various forms and helps to develop the most effective anti-corruption measures. Corruption monitoring through its research and assessment helps to implement anti-corruption measures more effectively. Both quantitative and qualitative methods are applied during the research of corruption.

Quantitative methods include surveys to assess public opinion. This is the most commonly used diagnostic tool for assessing levels of corruption. As a rule, these surveys are sources of data on certain elements or types of corruption in the country. Most of these researches are aimed at identifying subjective opinions of the respondents using direct questions about experience and practice of citizens/or private enterprises (Povitkina and Wysmulek 2016, Richards 2016). Businessmen are assigned to often surveyed group, as they are aware about the state of affairs in this area.

Among them, one of the known is the methodology for determining corruption perception indexes in the countries of the international community, developed by the "Transparency International" anticorruption agency. This methodology has a multi-faceted nature, since the agency includes offshore companies, non-transparency of financial institutions and excessive payments to managers in the concept of "corruption" (CPI 2016). There is also a similar methodology for an international survey of crime victims used by the United Nations, which is based on the use of telephone and personal interviews with victims and witnesses of blackmailing offenses (ICVS 2008). Along with this, at the request of government bodies the surveys with the use of different forms of questionnaires in the countries are conducted. Based on the data obtained, the following indexes are calculated: corruption perceptions index; bribery index; corruption index in society in a certain sector.

The purposes of the qualitative research may be different. Some of these surveys have a clear anticorruption orientation, others - analyze the institutional systems in which corruption continues to flourish. The qualitative method is designed to use different approaches, such as checklists, expert surveys, expert interviews, focus group researches, and so on (Brandt and Eiro 2016, Varrich 2016). The main advantage of the research of corruption qualitative characteristics is that these researches make it possible to clearly outline and analyze the extent of a particular issue or the state of corruption in a particular sector. In some cases, data and relevant analytical materials can be used as support in the strategy development, as well as for taking specific measures to solve a specific problem or impact on a specific sector.

We used a quantitative method of research - a mass survey using a questionnaire, through a personal interview with a respondent (face-to-face). A survey was conducted among representatives of small and medium-sized businesses. The sample includes 500 respondents. Representatives of civil servants were interviewed as a control group, and the sample comprised 500 respondents. In both cases, the target sample was used. In particular, to select the sample of SME representatives, we calculated the general population by country and by region. Then a quota sample was compiled. The survey involved those representatives of SMEs that are members of the National Chamber of Entrepreneurs. For the survey, we selected civil servants who, by the nature of their activities, directly interact with the SME. The questionnaire included 24 questions and 4 social and demographic questions. The questionnaire consisted of two blocks of questions. The first is questions that reflect assessment of the corruption phenomenon. The second is the attitude of respondents to the results of researches on corruption. Due to the fact that we planned to compare the ratio of the two target groups to the corruption, we used the same half-closed questions in the questionnaires. The geography of the research covers 14 regions, the capital and the city of republican significance (Astana and Almaty).

The research was based on the following categories and empirical categories of analysis (Table 1).

\section{Results of research and discussion}

\section{Characteristics of respondents}

The sample of the business group included 500 respondents from 14 regions of Kazakhstan, the capital and a city of national importance. A quota sample was used. 52.4\% of men and $47.6 \%$ of women were surveyed. Among the respondents, the most significant was the age group of the 
Table 1. Tasks categorization and empirical measures

\begin{tabular}{|l|l|l|}
\hline \multicolumn{1}{|c|}{ Tasks } & \multicolumn{1}{|c|}{ Original notion } & \multicolumn{1}{c|}{$\begin{array}{c}\text { Empirical categories (indicators for measuring, } \\
\text { analysis categories) }\end{array}$} \\
\hline $\begin{array}{l}\text { Key factors of influence on the } \\
\text { situation of corruption practices }\end{array}$ & $\begin{array}{l}\text { Corruption as occurrence or phenomenon } \\
\text { of social life, bribe, business, social, poli- } \\
\text { tical corruption }\end{array}$ & $\begin{array}{l}\text { Determination of characteristics of corruption re- } \\
\text { lations, impact of social and demographic parame- } \\
\text { ters on corruption perceptions }\end{array}$ \\
\hline Potential corruptogenic spheres & $\begin{array}{l}\text { Socially significant spheres of public life, } \\
\text { differentiation of corruption types }\end{array}$ & $\begin{array}{l}\text { Social environment of corruption, social support } \\
\text { or denial settings }\end{array}$ \\
\hline $\begin{array}{l}\text { The nature of state anti-corruption } \\
\text { policy }\end{array}$ & $\begin{array}{l}\text { Principles of state anti-corruption policy, } \\
\text { implementation mechanisms, impact and } \\
\text { effectiveness of state policy }\end{array}$ & $\begin{array}{l}\text { Awareness and support of the main directions of } \\
\text { state policy, reflected in the mass media }\end{array}$ \\
\hline $\begin{array}{l}\text { Influence of external assessments } \\
\text { and results of sociological research } \\
\text { on corruption perception by the } \\
\text { population }\end{array}$ & $\begin{array}{l}\text { Role of international assessments in } \\
\text { corruption perception by the population, } \\
\text { degree of confidence in domestic resear- } \\
\text { ches }\end{array}$ & $\begin{array}{l}\text { Public attitudes and assessment of the results of } \\
\text { sociological researches }\end{array}$ \\
\hline
\end{tabular}

respondents from 30 to 45 , that constituted $56.8 \%$ The second - from 46 to $60-28.6 \%$. Young entrepreneurs from 18 to 29 accounted for $11.8 \%$. Regarding educational level, the respondents with secondary vocational education (college) $-49.2 \%$ and higher education (university) $-47.6 \%$ are more likely to meet. $1.8 \%$ of the respondents have secondary education (full secondary school). As for ethnicity, 55.6\% of Kazakhs, $42.2 \%$ of Russians and $2.2 \%$ of representatives of other ethnic groups are represented in the sample.

The social and demographic characteristics of the interviewed civil servants (500 respondents) are as follows: men $-40.2 \%$, women $-59.8 \%$. The age composition: from 18 to $29-26.2 \%$, from 30 to $45-20.6 \%$, from 46 to $60-$ $20.6 \%$, from 61 and over $-1.0 \% .99 .8 \%$ of the respondents among civil servants have a higher education and $0.2 \%$ has a degree.

\section{Results}

The government of Kazakhstan seeks to create the most favorable conditions for SMEs development. In all program documents, development of SMEs is defined as a priority. There are various support institutions in the country. In recent years, activity of the National Chamber of Entrepreneurs has increased. Despite such government efforts, contribution of SMEs to GDP and employment is negligible (Fig. 1).

In this regard, researches are being conducted to identify the reasons for the SMEs slow development against the backdrop of increased state support for their activities. It is established that the average value of entrepreneurs' satisfaction with the success of their own business is $68 \%$ of $100 \%$ (Tastulekova and Bukeeva 2016). This means that there are "problems" in development of business.

The research results confirmed the thesis of widespread corruption in the business sphere (Fig. 2).

SMEs and civil servants understand corruption as personal contacts ensuring cover up for (Fig. 3). The possibility of using official powers in their own interests - is the source of covering up for and taking of bribe as a form of remuneration for the service rendered. Therefore, the respondents reveal the nature of corruption in such a sequence. This conclusion indicates the existence among SMEs of the tradition of pulling strings as an integral condition of business development. The persistent character of tradition reproduces corruption relations.

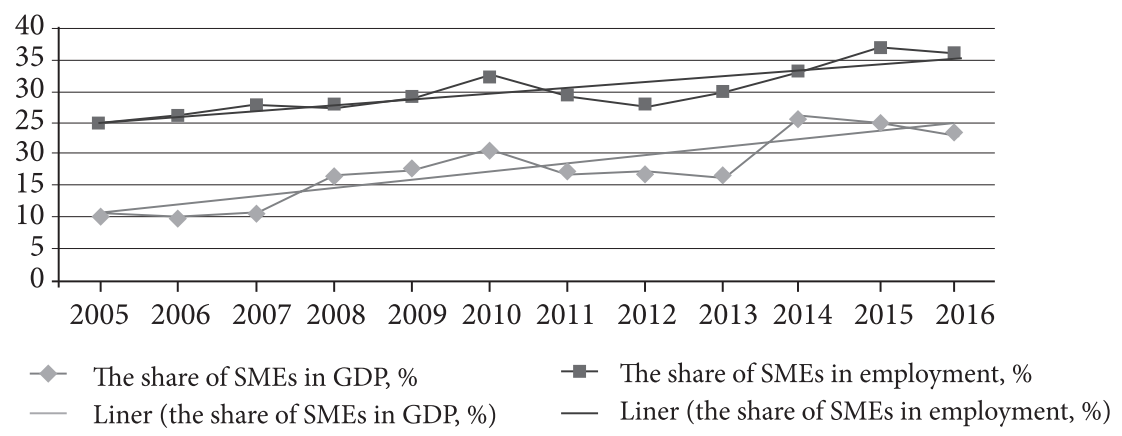

Note: Compiled according to the data of the Ministry of National Economy of the Republic of Kazakhstan.

Fig. 1. Dynamics of SMEs contribution to GDP and employment in the Republic of Kazakhstan for 2005-2016, \% 


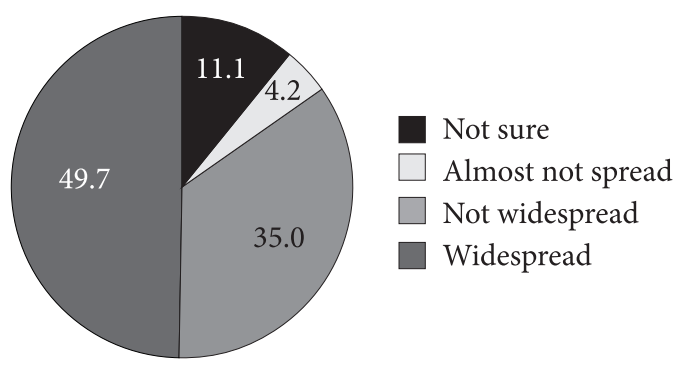

Fig. 2. Expansion of business corruption in Kazakhstan, \%

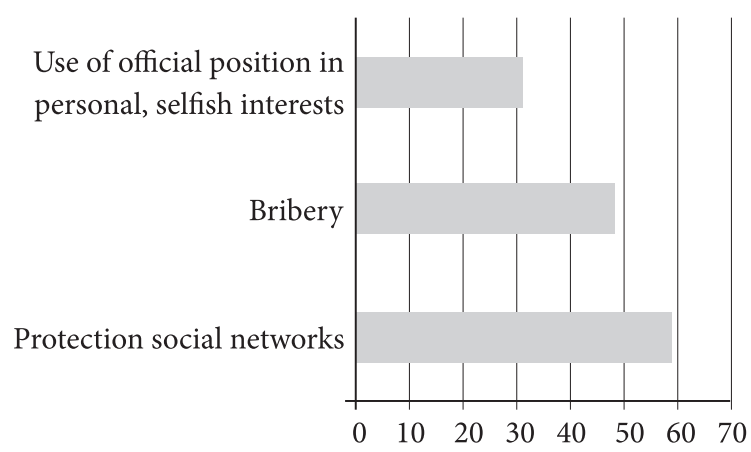

Fig. 3. Definition of the "corruption", \%

Corruption, which began with bribes, today has multiple forms of manifestation due to the ramification and complication of the subject and terms of transactions. The research found that if for SMEs a bribe is a convenient way to resolve issues, then for the civil servants, a bribe is a forced measure (Table 2). Consequently, both groups recognize that following formal rules are associated with high transaction costs and they consider paying bribes as an "easy" way of bypassing the rules. This means that, despite the government's efforts to create a favorable business environment, SMEs consider their environment unfavorable. Our results support the research findings in the Business Climate, which showed that $16 \%$ of respondents noted that corruption helps the development of business (Business Climate 2016).

We believe that the action of administrative barriers bring to "high" price of obedience to the law. If the administrative barriers prevail in the economy, then a corrupt transaction, bypassing the rules, becomes the rational choice of SMEs based on comparison of the "cost-benefit" of functioning in the sphere of legal economy. However, in real life, any rule can be perceived as a barrier, since it places a restrictive framework for activities. According to entrepreneurs, most of the rules are barriers, because they hinder rapid growth and maximization of profit (Suleimenova 2005). The government believes that all the created rules are designed to streamline the activities of state and business structures, as well as protect the domestic market.

Despite this, the results of our survey confirm that the idea of creating and maintaining a competitive business pushes entrepreneurs to participate in business networks that include not only entrepreneurs, but also representatives of state bodies. Entrepreneurs are convinced that "the vertical take-off of business structures is based on activities that involve an element of lobbying in the halls of power, without which the super-profitability of transactions would be unlikely" (Barsukova 2000). Our study also records that the use of ties, relatives, friends and acquaintances to informally resolving problems in Kazakhstan is quite common (60.8\% - SME, 56.4\% - civil servants) (Table 3).

Table 3. Dissemination of the use of networks, relatives, friends and acquaintances to informally resolve problems in Kazakhstan, \%

\begin{tabular}{|l|c|c|}
\hline & SMEs & Civil servants \\
\hline Very common & 7.0 & 2.3 \\
\hline Quite common & 60.8 & 56.4 \\
\hline Not very common & 19.6 & 24.4 \\
\hline Not common & 3.5 & 4.3 \\
\hline Not sure & 9.1 & 12.6 \\
\hline Total & 100 & 100 \\
\hline
\end{tabular}

Our research, as well as the research of the Institute of Economic Research, conducted in 2015, revealed the existence of a "lag" between the perception of corruption and the degree of respondents' participation in corruption. Respondents believe that corruption is widespread, but they themselves rarely participated in corrupt transactions.

Table 2. Assessment of paying bribes in two groups of respondents, $\%$

\begin{tabular}{|c|c|c|}
\hline & SMEs & Civil servants \\
\hline This is a convenient way to resolve problems & 42.7 & 37.6 \\
\hline This is necessary to resolve problems, almost all pay a bribe & 32.2 & 34.3 \\
\hline People are forced to pay a bribe, since there is practically no other way out & 39.9 & 38.9 \\
\hline I do not pay a bribe, and I do not care if others pay & 5.6 & 6.9 \\
\hline I do not pay a bribe, and I think that no one should pay a bribe & 9.1 & 5.6 \\
\hline Mentality of the people & 0.0 & 0.0 \\
\hline Not sure & 1.4 & 2.3 \\
\hline
\end{tabular}

Note: Respondents could choose several answers, so the sum of the answers is not equal to $100 \%$. 
Table 4. How would you assess the extent of corruption in Kazakhstan as a whole today?, \%

\begin{tabular}{|l|c|c|}
\hline \multirow{2}{*}{\multicolumn{1}{c|}{ Options }} & \multicolumn{2}{|c|}{$\%$} \\
\cline { 2 - 3 } & In Kazakhstan & In the sphere of work \\
\hline High & 32.4 & 19.8 \\
\hline Average & 41.9 & 33.2 \\
\hline Low & 18.7 & 22.4 \\
\hline No corruption & 1.6 & 18.6 \\
\hline Not sure & 4.7 & 6.0 \\
\hline Total & 100.0 & 100.0 \\
\hline
\end{tabular}

According to the results of the research, it can be concluded that entrepreneurs consider this problem to be acute, but are not ready to talk about their own experience in this regard. This is especially true for the southern regions of Kazakhstan (Business Climate 2016).

Comparing the overall level of corruption and corruption in their own sphere of activity, representatives of SMEs note a big difference. 32.4\% is a "high" level of corruption in Kazakhstan, and 19.8\% of SMEs respondents note "high" level in their own sphere (Table 4).

Business as one of the sectors of society can play a significant role in reducing the level of corruption. In the research, we tried to study how business representatives refer to information in the media about corruption, how important for them the publicity of such information.

\section{Conclusions}

This research analyzed the perception of corruption and the attitude of SMEs to corruption practices through a face-to-face survey of 500 representatives of SMEs and 500 civil servants.

The results of a sociological research allows for the following conclusions. Firstly, there is a "gap" between perception of corruption and degree of the SMEs involvement in corrupt practices. In particular, SMEs perceive corruption as widely spread. At the same time, they argue that they were rarely involved in corruption relations. Secondly, it revealed that representatives of SMEs are not ready to talk about their own experience of participation in corrupt transactions. Thirdly, differences in the perception of corruption among representatives of SMEs and civil servants have been revealed. Thus, representatives of SMEs perceive a bribe (as a form of corruption) as a way to quickly solve problems. At the same time, civil servants believe that bribes are given in a "hopeless" situation. Fourth, unwillingness of SMEs representatives to implement anti-corruption measures in the industry they work is revealed. This is confirmed by our data, where it is established that SMEs representatives participating in the survey assess the level of corruption in their own industry lower than in other industries. Fifthly, a low level of interest of SME representatives in the publicity and openness of relations between business and the state has been revealed.

Thus, the results of the research testify to the need to strengthen the corporate culture in SMEs, aimed at introducing a policy of openness and "zero" tolerance for corruption. One of the measures to implement this policy can be the exchange of information between SMEs and government agencies on open digital platforms. Another one can be the implementation of educational programs that clarify the legal framework and tools to control corruption. In addition, there is most important to develop social responsibility of the SME (e.g. Lee et al. 2015). The experience of Japan shows that the introduction of training programs for entrepreneurs on CSR, allows them to subsequently pursue an effective CSR policy, improve management and business environment (Makoya 2017).

\section{Funding}

This work was supported by the Science Committee of the Ministry of Education and Science of the Republic of Kazakhstan under Grant 3680/ГФ4 "Sociological measurement of corruption: research methodology and perception of society to the results of research" (2015-2017).

\section{References}

Adamoniene R, Andriuscenka J (2013) The small and mediumsized enterprises: the aspects of appliance the principles of strategic management. Economics and Management 12: 548-555.

Aldrich HYe, Wiedenmayer G (1993) From Traits to Rates: An Ecological Perspective on Organizational Foundings. In: Katz JA, Brockhous RH (Eds) Advances in Entrepreneurship, Firm Emergence and Growth Greenwich. CT: JAI Press, 145-195.

Ayandibu AO, Houghton J (2017) The role of Small and Medium Scale Enterprise in local economic development (LED). Journal of Business and Retail Management Research (JBRMR) 11 (2): 133-139 http://www.jbrmr.com/admin/content/pdf/i26_c-262.pdf

Barsukova S (2000) Informal economy and the network organization of space in Russia. The world of Russia 1: 52-68 [Barsukova S (2000) Neformal'naya ekonomika i setevaya organizatsia prostranstva Rossii. Mir Rossii 1: 52-68].

Brandt C, Eiro F (2016) Qualitative corruption research methods. In: Schwikerath A, Varraich A, Smith L (Ed) How to research corruption? Conference Proceeding Interdisciplinary Corruption Research Forum. Amsterdam, 34-40 https:// www.ssoar.info/ssoar/bitstream/handle/document/52393/ ssoar-2017-schwickerath_et_al-How_to_research_corruption_Conference.pdf? sequence $=1$

Business climate (2016) Special review on corruption and the shadow economy. Atameken NCE of RK. ERI JSC [Delovoy klimat (2016) Spetsial'nyy obzor po korruptsii i tenevoy ekonomike. NPP Atameken. AO IEI] atameken.kz/uploads/ content/files/Спец_обзор\%20по\%20коррупции-2016.pptx 
Collins J, McMullen J, Reutzel C (2016) Distributive justice, corruption, and entrepreneurial behavior. Small Business Economics 47 (4): 981-1006. https://doi.org/10.1007/s11187016-9751-8

CPI (2016) Corruption Perception Index 2016 https://www. transparency.org/news/feature/corruption_perceptions_index_2016

Doing Business (2017) Doing Business 2017: Equal Opportunity for all http://www.doingbusiness.org/reports/global-reports/ doing-business-2017

Fazekas M (2017) Red tape, bribery and government favoritisms: evidence from Europe. Crime, Law and Social Change: 1-27 https://www.researchgate.net/profile/ Mihaly_Fazekas/publication/318169123_Red_tape_bribery_and_government_favouritism_evidence_from_Europe/ links/5968a6a8458515e9afa76b61/Red-tape-bribery-andgovernment-favouritism-evidence-from-Europe.pdf

Emerson P (2006) Corruption, competition and democracy. Journal of Development Economics 81 (1): 193-212 http:// citeseerx.ist.psu.edu/viewdoc/download?doi=10.1.1.469.6975 \&rep=rep1\&type $=$ pdf

Galli E, Mascia D, Rossi S (2017) Does Corruption Affect Access to Bank Credit for Micro and Small Businesses? Evidence from European MSMEs: ABDI Working Paper Series: 19 https://think-asia.org/handle/11540/7178

Gamberoni E, Gartner C, Giordano C, Lopez-Garcia P (2016) Is corruption efficiency - enhancing? A case study of nine Central and Eastern European countries: Working paper \#1950/August https://www.ecb.europa.eu/pub/pdf/scpwps/ ecbwp1950.en.pdf

Golovshchinsky K, Parkhomenko S, Rimsky V, Satarov G (2004) Business and Corruption: Problems of Counteraction: Final Report. M.: Indem [Golovshchinskiy K, Parkhomenko S A, Rimskiy V, Satarov G (2004) Biznes i korruptsiya: problemy protivodeystviya. Itogovyy otchet. M.: Indem] http://www. anti-corr.ru/cipe/CIPEbriefing.htm

ICVS (2008) International Crime Victim Survey http://wp.unil. ch/icvs/questionnaires/questionnaire-2008/

IEER (2013) Corruption and Satisfaction: SME Managers on Corruption http://gvi.hu/research_details/135/corruption_ and_satisfaction:_sme_managers_on_corruption

Krammer S (2016) Greasing the wheels of change: bribery, institutions, and new product introductions in emerging markets http://eprints.whiterose.ac.uk/121645/1/S_Krammer_Bribery_New_Prod_Innovations_JOM.pdf

Lee K, Herold D, Yu A (2015) Small and Medium Enterprises and Corporate Social Responsibility Practice: A Swedish Perspective. Corporate Social Responsibility and Environmental Management 23 (2): 88-99. https://doi.org/10.1002/csr.1366

Mahfuzur R, Moshfique U, Lodorfos G (2017) Barriers to enter in foreign markets: evidence from SMEs in emerging market. International Marketing Review 34 (1): 68-86 http://www.emeraldinsight.com/doi/abs/10.1108/IMR-102014-0322

Makoya K (2017) CSR Challenges and Strategies for Small Businesses http://www.tokyofoundation.org/en/articles/2017/ csr-for-small-businesses
OECD (2017a) Economic Policy Reforms. Going to Growth: 348.

OECD (2017b). Enhancing the Contributions of SMEs in a Global and Digitalised Economy: 21.

OPORA NKO (2014) Small Business and Corruption: Prospects for Overcoming [OPORA NKO (2014) Malyi bizness i korruptsyia: perspectivy preodolenya] http://opora.ru/ news/rezultaty-issledovaniya-opory-rossii-malyj-biznes-ikorruptsiya-perspektivy-preodoleniya.html

Povitkina M, Wysmulek I (2016). Quantitative methods in researching corruption: surveys, cross-national studies, and measurement issues. In: Schwikerath A, Varraich A, Smith L (Ed) How to research corruption? Conference Proceeding. Interdisciplinary Corruption Research Forum. Amsterdam, 25-33.

Richards L (2016) Using Survey Methods to Research Corruption. In: Schwikerath A, Varraich A, Smith L (Ed) How to research corruption? Conference Proceeding. Interdisciplinary Corruption Research Forum. Amsterdam: 4-12.

Ronald U, Mendoza R, Lim A (2015) Grease or Sand in the Wheels of Commerce? Firm Level Evidence on Corruption and SMES. International Development 27 (4): 415-439. https:// doi.org/10.1002/jid.3077

Schwab K (2017) The Global Competitiveness Report 2016-2017. WEF: 400.

Shagbazian G, Aistov A (2017) Entrepreneurial Activity and Institutions. The Impact of Rule of Law and Control of Corruption (July 11, 2017) https://ssrn.com/abstract=3000427

Skriba A, Urban D (2015) Condition of corruption in Belarus in perception of small and medium business: Policy Discussion Paper. IPM Research Center http://eng.research.by/publications/dp/pdp1502/

Suleimenova G (2005) Administrative barriers in the development of entrepreneurship. Kazakhstan-spectrum 2: 91-97 [Suleymenova G (2005) Administrativnye bar'yery v razvitii predprinimatel'stva. Kazakhstan-spektr 2: 91-97] http://kisi. kz/img/docs/1279.pdf

Tastulekova A, Bukeeva A (2016) Businessmen of the RK: Yes, corruption is a problem, but we have not encountered it [Tastulekova A, Bukeeva A (2016) Predprinimateli RK: Da, korruptsiya - problema, no my s ney ne stalkivalis']. https:// forbes.kz/stats/optimistyi_pessimistyi_i_dorogi_1

Uruzbaeva N (2016) Problems and ways of business climate improving in the regions. R-Economy 2 (1): 132-142. https:// doi.org/10.15826/recon.2016.2.1.012

Varrich A (2016) Making Sense of Corruption through Interviews. In: Schwikerath A, Varraich A, Smith L (Ed) How to research corruption? Conference Proceeding. Interdisciplinary Corruption Research Forum. Amsterdam: 13-20.

Virglerová S, Dobes K, Vojtovič S (2016) The Perception of the State's Influence on its Business Environment in the SMEs from Czech Republic. Revista "Administratie si Management Public" (RAMP) 26: 78-96 https://www.ceeol.com/search/ article-detail $? \mathrm{id}=426884$

Xun W, Chandramohan K, Bali A (2016) Corporate Governance and Bribery: Evidence from the World Business Environment Survey. In Financial Crimes: Psychological, Technological, and Ethical Issues: 219-234. 
Gulimzhan SULEIMENOVA. Her research interest is related to SMEs, public administration, performance evaluation, and perception of corruption.

Aigul SADVOKASSOVA is the Head of the Center for Interethnic and Interconfessional Studies in Central Asia of the Academy of Public Administration under the President of Kazakhstan. Head of the research project "Sociological measure of corruption: the methodology of the study and attitude of society to research", 2015-2017.

Botagoz RAKISHEVA is the Founder/ Research advisor of the Research Institute "Public Opinion". Her research interest includes SMEs development, NGO, ethnic group and etc.

Arman NURMAGANBETOV is PhD student in the Institute of Management of the Academy of Public Administration under the President of Republic of Kazakhstan. His research interest is related to SMEs support policy. 